\title{
Biosecurity in dairy goat farms
}

\author{
Bruna Carolina Ulsenheimer ${ }^{1}$ (D) Daniela Isabel Brayer Pereira ${ }^{2}$ (D) \\ Mateus Matiuzzi da $\operatorname{Costa}^{3}$ Helton Fernandes do Santos ${ }^{1}$ (D) Rodolfo de Moraes Peixoto ${ }^{4}$ (D) \\ Luís Antonio Sangioni ${ }^{1}$ Sônia de Avila Botton ${ }^{1 *} \mathbb{D}$
}

${ }^{1}$ Programa de Pós-Graduação em Medicina Veterinária, Departamento de Medicina Veterinária Preventiva, Centro de Ciências Rurais (CCR), Universidade Federal de Santa Maria (UFSM), 97105900, Santa Maria, RS, Brasil. E-mail: sabott20@gmail.com. *Corresponding author. ${ }^{2}$ Departamento de Microbiologia e Parasitologia, Instituto de Biologia, Universidade Federal de Pelotas (UFPel), Pelotas, RS, Brasil. ${ }^{3}$ Projeto Irrigação Senador Nilo Coelho, Universidade Federal do Vale do São Francisco (UNIVASF), Petrolina, PE, Brasil. ${ }^{4}$ Instituto Federal do Sertão Pernambucano (IFSertãoPE), Petrolina, PE, Brasil.

ABSTRACT: The goat milk industry has unquestionably grown in recent years due to the high demand for dairy products, which are considered nutritious and hypoallergenic. As a result, security measures are required in the production chain to provide consumers with safe products, although the concept of biosecurity is still incipient in Brazilian goat farming. Therefore, this study aimed to review the main biosecurity measures applied to dairy goat farms and suggest a program that contemplates these measures to promote animal health and welfare, given that biosecurity bolsters environmental sustainability and improves this agricultural sector. Biosecurity programs (BP) are composed of a set of measures and procedures aimed at herd health and applied in all stages of animal husbandry, interacting with different sectors that make up the production system and providing a set of policies and operational norms to protect herds against potentially pathogenic agents. Thus, BP require planning, execution, monitoring, audits, updates, understanding of the procedures, and awareness of those involved in the production chain. In addition, it includes continuing education programs and the development of contingency plans for specific emergencies. The information included in this study provides input to dairy goat farms to implement practices that improve the productivity of this agricultural sector Key words: small ruminants, animal health, prophylactic measures, control measures, infectious diseases, parasitic diseases.

Biosseguridade em propriedades de caprinos leiteiros

RESUMO: A caprinocultura leiteira é um setor produtivo em crescimento, devido à alta demanda dos produtos lácteos considerados nutritivos e hipoalergênicos. Em consequência disso, são exigidas medidas de segurança na cadeia produtiva a fim de fornecer produtos inócuos ao consumidor. No entanto, os conceitos de biosseguridade ainda são incipientes na caprinocultura brasileira. Desta forma, este estudo tem a finalidade de revisar as principais medidas de biosseguridade aplicadas à caprinocultura leiteira e sugerir um programa que contemple estas medidas visando promover a saúde e o bem-estar animal. Além disso, a biosseguridade propicia a sustentabilidade do meio ambiente e potencializa melhorias neste setor agropecuário. Salienta-se que um programa de biosseguridade (PB) é composto por um conjunto de medidas e procedimentos de atenção à saúde do plantel, aplicados em todas as etapas da criação animal, interagindo com diversos setores que compõe o sistema produtivo, além de propiciar a implantação de um conjunto de políticas e normas operacionais, com o objetivo de proteger os rebanhos contra a introdução de qualquer agente infeccioso potencialmente patogênico. $O$ PB necessita de planejamento, execução, monitoramento, auditorias, atualizações, bem como demanda de compreensão dos procedimentos e da sensibilização de todos os envolvidos nos processos da cadeia produtiva. Adicionalmente, inclui programas de educação continuada de todos os individuos e a elaboração de planos de contingência para situações emergenciais especificas. As informações incluídas neste estudo fornecerão aporte às propriedades de caprinocultura de leite para a implementação de ações que promovam melhorias na produtividade deste setor agropecuário.

Palavras-chave: pequenos ruminantes, saúde animal, medidas profiláticas, medidas de controle, doenças infectocontagiosas, doenças parasitárias.

\section{INTRODUCTION}

Milk is one of the main foodstuffs in the daily diet of the Brazilian population, and this product has shown great prominence in production in the country, achieving notable production rates of bovine milk on a global scale (MATIUZZO \& SILVA, 2018). The increased demand for dairy products has led to higher goat milk production (DAL MONTE et al., 2010), and according to the 2017 Agricultural Census, 25,353,000 liters of milk were produced by 106,553 goats in the 15,717 establishments throughout Brazil. Most production takes place in northeastern Brazil, such as the states of Paraíba (5,627,000 liters/ milk/year) and Bahia $(4,665,000$ liters/milk/year) (BRASIL, 2017a).

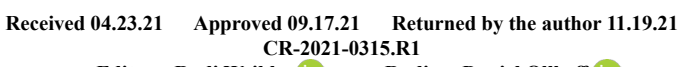


Goat milk is a safe and healthy alternative for feeding children and adults who are sensitive and/ or allergic to components present in milk from other animal species. Moreover, this product is considered one of the most complete foodstuffs and contains casein, globulin, albumin, and lower $\alpha$-s-1-casein content and formation of fat globules, facilitating the digestive process (SILVA \& DEL VALLE, 2018). Due to the importance of ensuring food safety to consumers, the quality of the milk produced in terms of its physicochemical and microbiological composition is of utmost relevance (LEIRIA et al., 2018). Thus, Brazilian Legislation No. 13854 took effect on July 8, 2019, and began to regulate goat milk and production quality for human consumption (BRASIL, 2019). As a result, the proper sanitary condition of the herd is essential and directly associated with adopting a set of good practices directed at preventing diseases (SACHET et al., 2013). Several studies have reported that the main sanitary problems of dairy farms are the lack of hygiene on the property and the absence of good management practices (PEIXOTO et al., 2012; VESCHI et al., 2016).

In order to minimize the adverse effects caused by pathogens in animal production and public health, implementing effective biosecurity programs (BP) stands out as a valuable alternative, albeit this practice already occurs in poultry and pig production systems (BONATTI \& MONTEIRO, 2008; MORÉS et al., 2017). Despite Brazil recently organizing the National Goat and Sheep Health Program (PNSCO), biosecurity in dairy goat farming is still incipient, as proven by the lack of research on the theme, thus indicating the need to develop a biosecurity plan aimed at these establishments in the country.

Therefore, this study aimed to review and propose biosecurity measures for dairy goat farms to improve the health status of herds in this relevant agricultural sector and promote One Health, which is the connection between the health of people, animals, and the environment.

\section{Article selection}

A systematic review was carried out according to the PRISMA flow chart, as suggested by MOHER et al. (2009). We searched for scientific articles containing recommendations on biosecurity in livestock farms and informative documents of national programs that ensure the production and quality of goat dairy products while considering that biosecurity in dairy goat farms is still incipient in Brazil. Hence, a two-stage search was carried out using four databases (Web of Science, Pubmed,
Scopus, and Google Scholar). The selection criteria included articles written in English and Portuguese and published between the years 2000 and 2020 . Stage I consisted of a literature survey using the terms "biosecurity" and "biosafety," "goat," and "milk quality" (n=53,211).

As no relevant scientific publications specifically addressing biosecurity measures in goat farming were found, another literature review (Stage II) was carried out addressing biosecurity programs for other livestock species using the terms "biosecurity" and "biosafety," "swine," "chicken," "cow," and "horse" (n=105,166). Stages I and II were performed separately, and duplicate articles were excluded. Articles employing the search terms "biosecurity" and "biosafety" that were unrelated to the scope of this study and/or unavailable in full (e.g., title and abstract only) were excluded. The selected articles of Stages I and II were evaluated according to the eligibility criteria of this study: written in English or Portuguese and containing some biosafety measure or recommending biosafety for any of the livestock species used in the search terms. After this analysis, the 59 remaining scientific articles were included in the qualitative analysis, leaving only 29 for the quantitative analysis due to presenting similar ideas as discussed herein. All the steps of this process are illustrated in figure 1.

A literature search was also performed on websites related to dairy goat farming in an attempt to identify BP in dairy goat production, and several manuals and programs were found that reported biosecurity measures for goat farming in some countries. Nonetheless, these documents only suggested isolated biosecurity measures. Thus, we propose a biosecurity program for dairy goat farms while considering the Brazilian agricultural context.

\section{Biosafety and biosecurity concepts}

TEIXEIRA \& VALLE (2010) defined biosafety as a set of measures aimed at preventing, minimizing, or eliminating risks inherent in research activities, production, education, technological development, and service provision that may jeopardize the health of humans, animals, and the environment or quality of the work developed. In addition, SESTI (2000) and ROCHA et al. (2010) used the term biosafety to refer to human health, having permanent rules aimed at providing low risks and high protection, in addition to the precautionary principle being implicit. In contrast, the term biosecurity was attributed to animal health, assumed risks, prevention, and/or safety related 


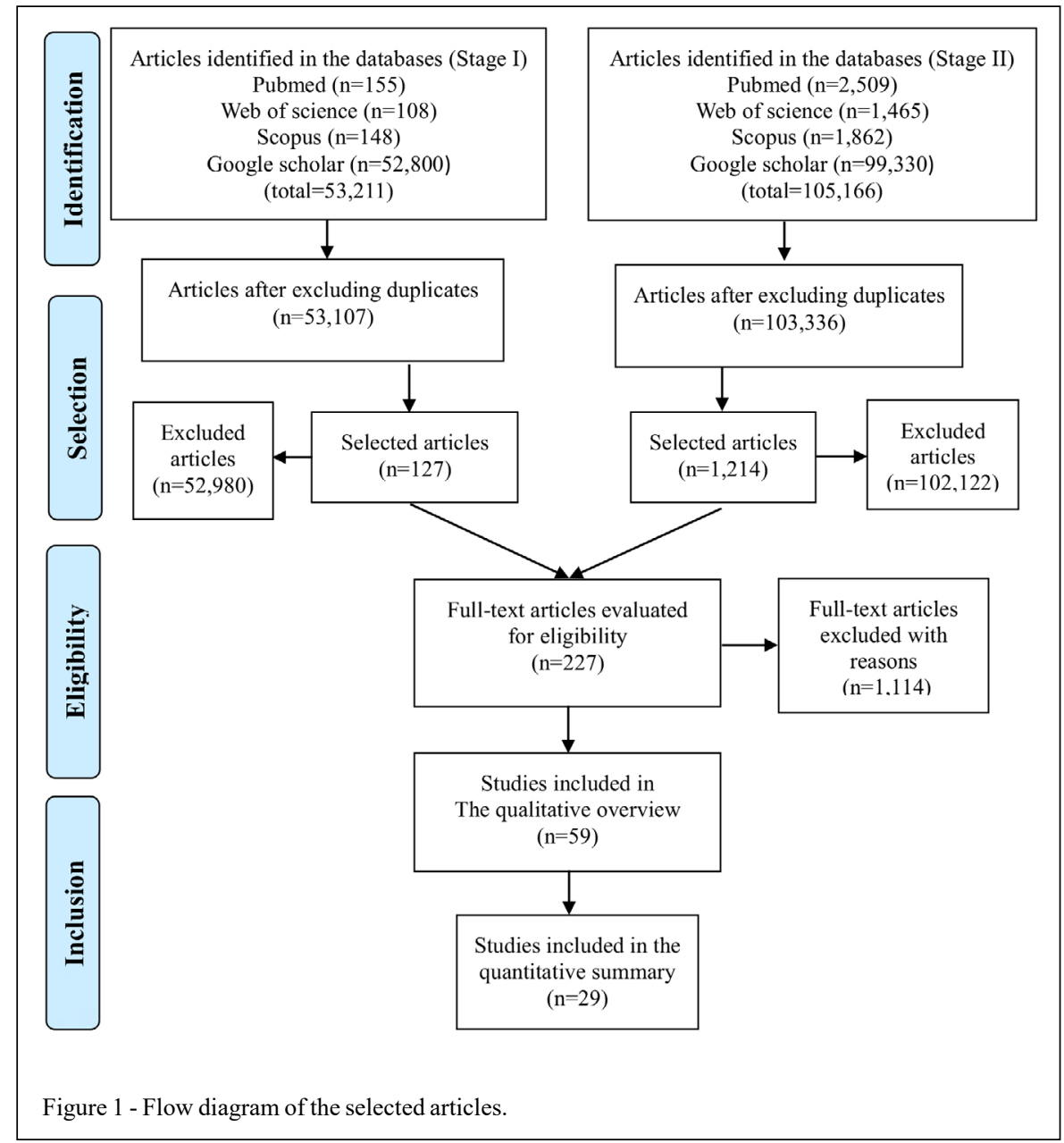

to Preventive Veterinary Medicine and Animal Production (SESTI 2000; MARTINS et al., 2019). Nevertheless, RIBEIRO \& GUIMARÃES (2017) chose to use the term biosecurity to encompass all activities related to promoting One Health, including human and environmental safety and animal health. In this article, the term biosecurity was used as defined by SESTI (2000) in the livestock production chain, which is defined as the development and implementation of strict operational policies and standards aimed at protecting herds against potentially pathogenic agents.

\section{Biosecurity measures in dairy goat farms}

There are several factors that directly interfere in the production of dairy goats in Brazil, to be considered inside and outside the properties, which can limit the increase in productivity and quality of goat milk produced, among the various factors found in the country, it is possible to highlight: herd genetic potential, production seasonality, forage quality, tropical climate, animal management, disease control, and adequate herd nutrition (GONÇALVES et al., 2008).

Therefore, biosecurity plans must include a risk assessment to verify the forms of entry and dissemination of infectious agents on the properties. A BP is composed of a set of measures and procedures encompassing the health of the herd and applied in all stages of animal production, interacting with the various sectors that make up the production system (SESTI, 2000). Furthermore, BP are already firmly rooted in the poultry (JAENISCH, 2004; SESTI, 2000), pig (MORÉS et al., 2017), horse (CANADIAN FOOD INSPECTION AGENCY, 
2017), and dairy cattle (DENIS-ROBICHAUD et al., 2019) production industries. Nevertheless, research on BP applied in dairy goat production is still nonexistent. The closest known studies for this theme are by GUNTHER et al. (2019), who described the hygienic-sanitary measures for Q fever in goats in Australia and RON-ROMÁN et al. (2017), who reported the need for specific biosecurity measures for goat farming in Ecuador. Additionally, several manuals and programs addressing general biosecurity measures in goat farming in other countries were found on a handful of websites (U. S. DEPARTMENT OF AGRICULTURE, 2021; MEAT \& LIVESTOCK AUSTRALIA, 2021; GOVERNMENT OF CANADA, 2021; AFGHAN AGRICULTURE, 2021). Thus, there is an urgent need to develop a specific BP for dairy goat farms.

Implementing a BP starts with developing control measures based on specific standards and applying favorable daily labor practices in the production chain. One of the main goals of implementing an effective BP includes maintaining the herds free of or protected from harmful pathogenic agents that pose risks to public health, which can cause significant economic impacts on animal production. Therefore, an effective BP must oversee the implementation of biosecurity measures in dairy goat farming and contain the measures described below.

\section{Isolation of the property}

Correctly establishing the location of animal production areas is crucial to prevent numerous diseases. Properties should be isolated, and animal housing built away from other animal production establishments $(3 \mathrm{~km})$ and highways $(500 \mathrm{~m})$ to reduce the possibility of contamination (BONATTI \& MONTEIRO, 2008). Animal breeding facilities should also be erected far from busy roads, although they should be easily accessible to ensure the entry of necessary inputs, food, and pharmacological supplies (AMARAL et al., 2014; POSTMA et al., 2016).

\section{Traffic control}

The influx of people, animals, and vehicles must be strictly controlled, and this is critical to preventing the introduction of pathogens to the area (BRENNAN \& CHRISTLEY, 2012; DENISROBICHAUD et al., 2019). Personnel not part of the staff should be prohibited, and eventual access by professional contractors and employees should be controlled. It is also imperative that staff do not have contact with other animal production properties
(BONATTI \& MONTEIRO, 2008; MASSOTTI et al., 2017).

\section{Sanitizing procedures and training for cleaning and disinfecting properties}

A sanitizing system with a disinfection arch or any other method that allows cleaning and disinfecting vehicles should be installed at the entrance of the properties (BRENNAN \& CHRISTLEY, 2012; AMARAL et al., 2014). It is important that the disinfectant is prepared in the established period and according to the manufacturer's recommendations, observing the expiration date and correct concentration of the product (RUI et al., 2011).

Clean areas (internal) must be separated from dirty areas (external) (MASSOTTI et al., 2017). Maintaining a clean and organized environment inside the animal facilities provides better conditions for animal health, and cleaning feeding and water containers should be done on a regular basis. Debris should be removed around the facilities, and synanthropic species must be controlled, especially insects and rodents. The access of other animals, including domestic species (e.g., dogs and cats), should be limited as much as possible since they can also be carriers and disseminators of multiple infectious agents (AMARAL et al., 2014).

Additional procedures must be adopted to avoid cross-contamination by the feed, especially in the stages of animal feed production, transport, and storage. To maintain the nutritional and microbiological quality of the feed, it must be stored in proper and enclosed places protected from humidity and excessive heat (e.g., silos). The silo and the entire feed distribution system cannot have contact with synanthropic species to avoid food contamination (MAGALHÃES \& MAGALHÃES, 2017).

Clean and disinfected clothing and footwear must be provided to the staff and eventual visitors. Veterinarians and employees working on the property must change clothes and wear clean and work clothing during activities on the property, especially overalls and boots (BONATTI \& MONTEIRO, 2008; DENISROBICHAUD et al., 2019). Moreover, employees must be trained to correctly perform milking in order to maintain the quality of the milk, be aware of proper maintenance and cleaning of equipment, and be vigilant of possible changes in the teat and mammary gland of the animals (WILLIS et al., 2017).

\section{Animal management in the milking area}

Efficiently cleaning and disinfecting the equipment and milking area must be carried 
out to avoid sanitary problems and prevent milk residues from remaining in the milking buckets and/ or machines, which can act as a favorable culture medium for microorganism proliferation. Hence, it is worth mentioning that utensils and equipment must be cleaned and disinfected to ensure that they meet the standards required for quality milk (CONTRERAS et al., 2007; RUI et al., 2011). To prevent the occurrence of infectious diseases such as mastitis, caused by different types of microorganisms, including bacteria, fungi and viruses (GABLI et al., 2019; HUSSEIN et al., 2020), which affect the quality of the final product (WILLIS et al., 2017; PISANU et al., 2020).

Furthermore, it is crucial for the health status of the herd and milk quality that staff follow the milking line by starting with the females that never presented teat inflammation, followed by those that have already presented this kind of alteration but have been cured, and lastly, the animals with mastitis, although the milk from the latter must be discarded. Teat hygiene should begin by washing the teats with chlorinated water, then drying each teat with disposable paper towels when dirty with manure or mud, although this step is unnecessary when they are clean. Afterward, the black background mug test is also recommended to observe any evidence of lumps, pus, or blood. After milking, post-dipping should be performed by dipping $2 / 3$ of the teat surface in a $0.5 \%$ iodine solution with glycerin, and the animals should be kept standing to allow time to close the teat orifice and prevent microorganisms from entering the mammary gland. This can be achieved by feeding the animals in troughs as soon as they leave the milking area (EMBRAPA, 2014).

The milking area and equipment must be cleaned and sanitized daily. The containers used for feeding and water should also be cleaned periodically. In addition, animal waste should be removed and discarded appropriately for further treatment on the property (CONTRERAS et al., 2007; AMARAL et al., 2014; EMBRAPA, 2014).

\section{Herd health control measures}

Another important measure is to quarantine all animals that will be later introduced into the herd. Thus, it is necessary to have an area on the property designated to examine newly acquired animals (BRENNAN \& CHRISTLEY, 2012; SACHET et al., 2013). During the quarantine period, the animals must be inspected and clinical and laboratory tests should be performed to ensure the health status of the entire property. In addition to the quarantine area, isolation stalls for animals affected by infectious and parasitic diseases are highly urged, when possible (MAGALHÃES \& MAGALHÃES, 2017). Vaccination programs should be carried out according to the geographical region. Therefore, it is pivotal to know the diseases present in the region and for which there is compulsory vaccination (BRENNAN \& CHRISTLEY, 2012; POSTMA et al., 2016; CANADIAN FOOD INSPECTION AGENCY, 2017). Information regarding the recommended vaccination schedule for the region can generally be accessed on the local Agricultural Defense Agency website. In addition, it is noteworthy that for herd vaccinations, it is important to use individual needles for each animal, to avoid the transmission of the lentivirus that causes Caprine Arthritis Encephalitis (CAE), through the secretions of positive animals (POTARNICHE, et al., 2020).

\section{Monitoring/recording and communicating results for the appropriate adjustments}

Health monitoring must be instituted on the property to verify the effectiveness of the BP and prevent health problems in the herd and economic losses. Corrective measures can help anticipate possible sanitary challenges, and health monitoring should be practiced daily and routinely and directed at the animals, the environment, the flow of people and vehicles on the property, and the inputs used in the production system (BONATTI \& MONTEIRO 2008; CANADIAN FOOD INSPECTION AGENCY, 2017). The BP supervisor needs to keep records and communicate the results obtained during the plan and possible procedures to be adopted by the staff (ARAÚJO \& ALBINO, 2013).

Control and/or eradication of pathogens and synanthropic species

Diseases must be eradicated and/or controlled on the property. The Brazilian Ministry of Agriculture, Livestock, and Food Supply (MAPA) has prepared national plans covering the primary diseases to be controlled in different regions of the country, including specific plans for small ruminants (BRASIL, 2017b). In addition, Brazil has a national program aimed at small ruminants (PNSCO) under Normative Instruction No. 87 of December 10, 2004. Its main objective is to carry out epidemiological and sanitary surveillance of goat and sheep diseases through actions defined by the Secretariat of Agricultural Protection and executed by the State Official Services. Some states carry out actions, including registering the production sites, certifying the establishments, registering private veterinarians, 
animal transit control, notifying diseases, and sanitary surveillance.

Therefore, the BP must be in accordance with the national and state plans and include the central control and prevention measures for the main biological agents. Some diseases require mandatory notifications, and the person responsible for the property must notify the local agricultural defense agency when faced with maladies present on the list of the World Organization for Animal Health (OIE).

The pathogens responsible for these diseases can be transmitted via different routes, including aerosols (airborne droplets or particles), direct contact with open wounds, mucous membranes (eyes, nose, and mouth), blood and saliva, or indirect contact through fomites such as halters, ropes, hoof trimming material, feeding equipment, buckets, bottles, and udders. Transmission can also occur orally by ingesting the pathogen via contaminated food or water. In addition, the pathogens can spread by synanthropic animals (rodents, pigeons, and bats), domestic species (dogs, cats, cattle, and pigs) and vectors (insects and arachnids). An important and notifiable viral disease in goats is bluetongue, transmitted by blood-sucking insects of the Culicoides genus (MOTA et al., 2011; LOBÃO et al., 2014). Notably, the transmission of diseases with zoonotic potential can also occur in the caprine herds (BRENNAN \& CHRISTLEY, 2012; MAGALHÃES \& MAGALHÃES, 2017).

In some situations, the sanitary management of the properties may be lacking, leading to more curative actions to the detriment of preventive actions (PERDIGÃO et al., 2016; GUNTHER et al., 2019). The central preventive management strategies adopted in herds include antiparasitic treatment, vaccination, and udder hygiene procedures for milking. The practice of navel antisepsis in newborn kids still has low adherence in properties despite its importance in animal health. Other management options, including footbaths, isolating sick animals, and quarantining newly acquired animals, are seldom adopted in goat farming (PERDIGÃO et al., 2016). Furthermore, the current knowledge of biosecurity in this sector is minimal (ODETOKUN et al., 2017), making farms vulnerable to different pathogens.

In Brazil, some researchers have verified the occurrence of different diseases of infectious origin that affect dairy goats (ROSA et al., 2013; PERDIGÃO et al., 2016; MEGID et al., 2016 and SILVA \& DEL VALLE (2018). The primary diseases, respective etiological agents that most affect dairy goat herds, and their classification according to their origin (bacterial, viral, and parasitic) are listed in table 1. The diseases that affect dairy goats present a potential risk of dissemination and cause economic losses to the property due to decreased milk production, loss of milk, and animal death. Moreover, the inadequate management of sick animals represents a risk to public health, especially due to the transmission of potentially zoonotic diseases, both for people who work directly with the herd and the consumer (SACHET et al., 2013; POSTMA et al., 2016). Thus, preventing diseases via biosecurity measures is a determining factor for improving One Health and animal production.

When it comes to control measures, the use of periodic diagnostic tests for ailments of the most significant economic impact is another essential step in the process of disease control and eradication (SINGH et al., 2020). Therefore, it is pivotal to identify the most important diseases in the respective region and adopt a diagnostic routine. RODRIGUES et al. (2018) evaluated the periodic use of more sensitive diagnostic tests combined with management practices while focusing on controlling caprine encephalitis arthritis. Although the disease was not eradicated, prophylactic management practices combined with periodic serological tests and polymerase chain reaction were decisive in significantly reducing the number of seropositive animals in the herd.

\section{Auditing and updating the biosecurity program in dairy goat farms}

Audits and procedures for updating operational aspects are important tools and help monitor the progress of the BP, including the evaluation of all implemented norms and the occurrence of irregularities, to institute action plans and update the procedures adopted. Audits should be performed constantly and, if possible, monthly or bimonthly, to identify any points requiring adjustments (MAGALHÃES \& MAGALHÃES, 2017).

\section{Continuing biosecurity education}

To ensure the continuity and uniformity of a BP, training and continuing education of biosecurity are necessary for everyone involved in the production system. This action is considered fundamental for a successful BP (AMARAL et al., 2014), and all individuals should fully understand the importance of biosecurity and the benefits of implementing a BP for dairy goats farms (PENNA et al., 2010). Continuing education can take the forms of lectures, courses, workshops, and roundtable discussions that can be done face-to-face or remotely. These activities must be 
Table 1 - Major infectious and parasitic diseases in dairy goats.

\begin{tabular}{|c|c|c|c|}
\hline Bacterial & Viral & Parasitic & Fungal \\
\hline Clostridiosis: & Arthritis-Encephalitis & Coccidiosis: & Aspergillosis \\
\hline -Botulism & Bronchopneumonia & -Cryptosporidiosis & Dermatophytoses \\
\hline -Symptomatic carbuncle & Diarrhea & -Eimeriosis & Protothecosis \\
\hline -Enterotoxemia & Ecthyma contagiosum & -Isosporosis & \\
\hline -Gaseous gangrene & Foot-and-Mouth Disease & -Neosporosis & \\
\hline -Lameness & Bluetongue & -Toxoplasmosis & \\
\hline -Tetanus & Rabies & -Trypanosomiasis & \\
\hline Contagious Agalactia of Sheep and Goats & & Gastric Helminthiases & \\
\hline Brucellosis & & -Haemonchosis & \\
\hline Keratoconjunctivitis & & -Ostertagiosis & \\
\hline Neonatal diarrhea & & -Trichostrongylosis & \\
\hline Dermatophilosis & & Intestinal Helminthiases: & \\
\hline Caseous lymphadenitis & & -Bunostomiasis & \\
\hline Leptospirosis & & -Cooperiosis & \\
\hline Listeriosis & & -Strongyloidiasis & \\
\hline Mastitis & & -Nematodirosis & \\
\hline Paratuberculosis (Johne's disease) & & -Oesophagostomosis & \\
\hline Pneumonic Pasteurellosis (shipping fever) & & -Trichuriasis & \\
\hline Contagious Caprine Pleuropneumonia ${ }^{*}$ & & Pulmonary Helminthiases: & \\
\hline Foot Rot (infectious pododermatitis) & & -Dictiocaulosis & \\
\hline Salmonellosis & & Cestodiasis & \\
\hline \multirow[t]{8}{*}{ Tuberculosis } & & -Coenurosis & \\
\hline & & -Hydatidosis & \\
\hline & & Trematodiasis & \\
\hline & & -Fasciolosis & \\
\hline & & -Ectoparasitosis & \\
\hline & & -Myiases & \\
\hline & & -Pediculosis & \\
\hline & & -Scabies & \\
\hline
\end{tabular}

Source: Adapted MEGID et al., (2016).

*Disease still not diagnosed in Brazil.

foreseen in the BP and can be held two or three times a year, for example, and it is important to encourage everyone to participate in continuing education activities in order to identify the perceptions and doubts of those involved regarding biosafety applied to the work routine (ARAÚJO \& ALBINO, 2013).

\section{Contingency plans and emergency decisions}

There must be a contingency plan on the farm that encompasses a set of procedures and emergency decisions in case of unexpected events. First, the BP should focus on the diseases that cause economic losses to dairy goat farms, in addition to those of public health importance (AMARAL et al., 2014). ARAÚJO \& ALBINO (2013) reported that the main objective of a contingency plan is to provide a quick clarification, diagnosis, and rapid containment or solution to the problem at hand.

Since cattle raising in Brazil requires an increasingly higher quality of the product produced 
(milk), the BP becomes a priority and an essential tool for the national and international agribusiness. Biosafety procedures require planning, execution, monitoring, audits, updates, understanding the procedures, and awareness of everyone involved in the production chain, including continuing education programs and developing contingency plans for specific emergencies. Thus, in order to provide better hygienic and sanitary quality and ensure excellence in production, biosecurity measures must be adopted in dairy goat farms.

Finally, some perspectives are presented regarding biosecurity in animal production, specifically in dairy goats. The BP proposed in this study is applicable to all types of goat breeding, ranging from small farms, including the experimental facilities to large-scale industrial farms.

As previously mentioned, BP aim to prevent, control, or eradicate diseases in herds, and research in the area of mathematical modeling has helped maintain the health status of herds, allowing, for instance, the construction of quantitative indicators (health status) to assess the quality of animal health in rural properties or even developing models that simulate the dynamics of disease transmission. These models can be employed to improve disease or outbreak prevention plans and evaluate the efficiency and effectiveness of new control strategies (BEKIROS \& KOULOUMPOU, 2020). Considering that the $\mathrm{BP}$ is designed to ensure the health status of the herd, this tool is a promising opportunity to anticipate health problems.

\section{CONCLUSION}

The biosecurity measures presented in this study are pivotal to improving sanitary actions in dairy goat properties. Moreover, developing a BP is an indispensable tool to safeguarding the sanitary status of herds, ensuring the improvement of production processes and the quality of milk produced and, as a result, promoting One Health and contributing to the growth of the Brazilian agricultural sector.

\section{ACKNOWLEDGMENTS}

The authors thank the Brazilian research funding agencies: Coordenação de Aperfeiçoamento de Pessoal de Nível Superior (CAPES) (financial code 001), Conselho Nacional de Desenvolvimento Científico e Tecnológico (CNPq), and Fundação de Amparo à Pesquisa do Estado do Rio Grande do Sul (FAPERGS).

\section{DECLARATION OF CONFLICT OF INTEREST}

The authors declare that there are no conflicts of interest.

\section{AUTHOR'S CONTRIBUTION}

of this manuscript.

All authors contributed equally to the development

\section{REFERENCES}

AFGHAN AGRICULTURE. Goats. Available from: <http://bit. ly/2QtXcPF>. Accessed: Jan. 20, 2021.

AMARAL, P. F. G. P.; MARTINS, L. A.; OTUTUMI, L. K. Biosseguridade na criação de frangos de corte. Enciclopédia biosfera, Goiânia, v.10, n.18, p.664-685, 2014. Available from: $<$ https://bit.ly/3hy1TRd>. Accessed: Jul. 13, 2020.

ARAÚJO, W. A. G; AlBINO, L. F. T. Biosseguridade na Produção de Matrizes Pesadas. 2013. Available from: <https:// bit.ly/3aXioUt>. Accessed: May, 10, 2020.

BEKIROS, S.; KOULOUMPOU, D. SBDiEM: A new mathematical model of infectious disease dynamics. Chaos, Solitons and Fractals, v.136, p.1-16, 2020. Available from: $<$ https://bit.ly/2Fb5sii > . Accessed: Sept. 14, 2020. doi: 10.1016/j. chaos.2020.109828

BONATTI, A. R; MONTEIRO, M. C. G. B. Biosseguridade em Granjas Avícolas de Matrizes. Intellectus, v.4, n.5, p.316-330, 2008. Available from: <https://bit.ly/3jeDale $>$. Accessed: May, 14,2020 .

BRASIL. Diário Oficial da União. LEI No 13.854, DE 8 DE JULHO DE 2019. Available from: <https://bit.ly/32rNTCe $>$. Accessed: Jul. 19, 2020.

BRASIL. Censo Agropecuário, 2017a. Instituto Brasileiro de Pesquisa e Estatística (IBGE). Available from: < https://bit. ly/2Yet0sD>. Accessed: May, 07, 2020.

BRASIL. Programa Nacional de Sanidade dos Caprinos e Ovinos (PNSCO), 2017b. Ministério da Agricultura, Pecuária e Abastecimento- MAPA. Available from: $<$ https://bit. ly/2QqPYbK>. Accessed: May, 22, 2020.

BRENNAN, M. L.; CHRISTLEY, R. M. Biosecurity on Cattle Farms: A Study in North-West England, Plos one, v.7, n.1, p.1-8, 2012. Available from: $<$ https://bit.ly/2EHxDVd $>$. Accessed: May, 22, 2020. doi:10.1371/journal.pone.0028139.

CANADIAN FOOD INSPECTION AGENCY. National Farm and Facility Level Biosecurity Standard for the Equine Sector. p.1-51, 2017. Available from: $<$ https://bit.ly/2Q5hSKq >. Accessed: May, 08, 2020.

CONTRERAS, A. et al. Mastitis in small ruminants. Small Ruminant Research, v.68, p.145-153, 2007. Available from: $<$ https://bit.ly/2F7xLhr>. Accessed: Sept. 18, 2020. doi: 10.1016/j. smallrumres.2006.09.011. 
DAL MONTE, H. L. B. et al. Mensuração dos custos e avaliação de rendas em sistemas de produção de leite caprino nos Cariris Paraibanos. Revista Brasileira Zootecnia, v.39, n.11, p. 25352544, 2010. Available from: < https://bit.ly/34zyceG $>$. Accessed: Jun. 17, 2020.

DENIS-ROBICHAUD, D. et al. Biosecurity and herd health management practices on Canadian dairy farms. Journal of Dairy Science, v.102, n.10, p.9536-9547, 2019. Available from: $<$ https://bit.ly/2D0aXiz>. Accessed: Jun. 17, 2020. doi:10.3168/ jds.2018-15921.

EMBRAPA, Ordenha Higiênica de Leite de Cabras. Embrapa Caprinos e Ovinos, Sobral, CE, 2014. Available from: $<$ https://bit. ly/31wirDC $>$. Accessed: Jun. 17, 2020.

GABLI, Z.; DJERROU, Z.; GABLI, A. E.; BENSALEM, M. Prevalence of mastitis in dairy goat farms in Eastern Algeria. Veterinary World, v.12, n.10, p.1563-1572, 2019. Available from: $<$ https://bit.ly/3z4JMe5>. Accessed: Jul. 13, 2021. doi:10.14202/ vetworld.2019.1563-1572.

GONÇALVES, A. L. et al. Avaliação de sistemas de produção de caprinos leiteiros na Região Sudeste do Brasil. Revista Brasileira de Zootecnia, v.37, p.366-376, 2008. Available from: <https:// bit.ly/3xJB58M>. Accessed: Jul. 13, 2021. doi: 10.1590/S151635982008000200025 .

GOVERNMENT OF CANADÁ. Biosecurity Planning Guide for Canadian Goat Producers. Available from: < http://bit. ly/2OTjFVU>. Accessed: Jan. 01, 2021.

GUNTHER, M. J.; HELLERA, J.; HAYESA, L.; HERNANDEZJOVER, M. Dairy goat producers' understanding, knowledge and attitudes towards biosecurity and Q-fever in Australia. Preventive Veterinary Medicine, v.170, p.1-9, 2019. Available from: $<$ https://bit.ly/3hwygjh $>$. Accessed: Jun. 04, 2020. doi: 10.1016/j. prevetmed.2019.104742.

HUSSEIN, H. A. et al. Study on prevalence and bacterial etiology of mastitis, and effects of subclinical mastitis and stage of lactation on SCC in dairy goats in Egypt. Tropical Animal Health and Production, v.52, n.6, p.3091-3097, 2020. Available from: $<$ https://bit.ly/3if5Rzs $>$. Accessed: Jun. 13, 2021.doi: 10.1007/ s11250-020-02331-5.

JAENISCH, F. R. F. et al. Importância da Higienização na Produção Avícola. 2004. Available from: <https://bit. ly/2YCDsL4>. Accessed: May, 15, 2020.

LEIRIA, M. H. et al. Fatores que alteram a produção e a qualidade do leite: Revisão. Pubvet, v.12, n.5, p.1-13, Mai., 2018. Available from: <https://bit.ly/32sQdsr>. Accessed: May, 10, 2020. doi: 10.22256/pubvet.v12n5a85.1-13.

LOBÃO, F. M. et al. Língua azul em ovinos: uma revisão. Revta Bras. Reprod. Anim, v.38, p.69-74, 2014. Available from: $<$ https://bit.ly/3emc8bF>. Accessed: Jun. 13, 2021.

MAGAlHÃES, M. R.; MAGALHÃES, C. F. Biosseguridade na produção de suínos. Investigação, v.16, n.1, p.25-31, 2017. Available from: <https://bit.ly/2YBSQam>. Accessed: Mai. 22, 2020. doi: 10.26843/investigacao.v16i1.1728.

MARTINS, N. S. et al. Conhecimento de estudantes de medicina veterinária da universidade estadual do maranhão sobre biotecnologia, bioética e biossegurança. Pubvet, v.13, n.3, p.1-8, Mar, 2019. Available from: <https://bit.ly/3heqhHn>. Accessed: May, 15, 2020.

MASSOTTI, R. et al. Biosseguridade na produção de suínos. Revista de Ciências Agroveterinárias, Lages, v.16, n.2, p.128135, 2017. Available from: <https://bit.ly/3jkwouu $>$. Accessed: May, 15, 2020. doi:10.5965/223811711622017128.

MATIUZZO, A. G.; SILVA, A. M. Caracterização do consumo de leite no município de Campos de Júlio - MT. Nucleus Animalium, v.10, n.2, p.97-105, 2018. Available from: <https:// bit.ly/2EtkZcS>. Accessed: May, 15, 2020.

MEAT \& LIVESTOCK AUSTRALIA. Give goats a go. Available from: <http://bit.ly/2QmdRo5>. Accessed: Jan. 20, 2021.

MEGID, J.; RIBEIRO, M. G.; PAES, C. P. Doenças infecciosas em animais de produção e companhia. Rio de Janeiro: Rocha, 2016, 1294p. Accessed: May, 10, 2020.

MOHER, D. et al. Preferred reporting items for systematic reviews and meta-analyses: The PRISMA Statement. PLoS Med, v.6, n.7, 2009. Available from: <https://bit.ly/31GRw72>. Accessed: Jan. 22, 2021. doi: 10.1371/journal.pmed.1000097.

MORÉS, N.; CARON, L.; COLDEBELlA, A.; BORDIN, L. C. Biosseguridade mínima para granjas de suínos que produzem animais para abate. Documentos 185. Embrapa Suínos e Aves Concórdia, SC. Ministério da Agricultura, Pecuária e Abastecimento, 2017. Available from: $<$ https://bit.ly/3iYbeSx $>$. Accessed: Jun. 12, 2020.

MOTA, I. O. et al. Anticorpos contra vírus do grupo da língua azul em caprinos e ovinos do sertão de Pernambuco e inferências sobre sua epidemiologia em regiões semiáridas. Arquivo Brasileiro de Medicina Veterinária e Zootecnia, v.63, p.1595-1598, 2011. Available from: $<$ https://bit.ly/3kmAx4M>. Accessed: Jun. 14, 2021. doi: 10.1590/S0102-09352011000600045.

ODETOKUN, I. A. et al. Status of Laboratory Biosafety and Biosecurity in Veterinary Research Facilities in Nigeria. Safety and Health at Work, v.8, p.49-58, 2017. Available from: $<\mathrm{https}: / /$ bit.ly/32qkZSZ>. Accessed: May, 10, 2020.

PEIXOTO, R. M. et al. Fatores de risco para mastite infecciosa em cabras leiteiras criadas no estado da Bahia. Arquivos do Instituto Biológico, São Paulo, v.79, n.1, p.101-105, jan./mar., 2012. Available from: $<$ https://bit.ly/33CnoeV $>$. Accessed: Sept. 15, 2020. doi: 10.1590/S1808-16572012000100015.

PENNA, P. M. M. Biossegurança: uma revisão. Arquivos do Instituto Biológico, São Paulo, v.77, n.3, p.555-465, jul./set., 2010. Available from: $<$ https://bit.ly/3hq0SKM $>$. Accessed: May, 10,2020 .

PERDIGÃO, N. R. O. F.; OLIVEIRA, L. S.; CORDEIRO, A. G. P. C. Sistemas de Produção de Caprinos Leiteiros. In: FELISBERTO, N. R. de O.; OLIVEIRA, L. S.; CORDEIRO, A. G. P. C. Embrapa Caprinos e Ovinos, 2016, p.11-33. Accessed: May, 10, 2020.

PISANU, S. et al. Impact of Staphylococcus aureus infection on the late lactation goat milk proteome: New perspectives for monitoring and understanding mastitis in dairy goats. Journal of proteomics, v.221, p.103763, 2020. Available from: <https://bit.ly/3B3Zyr7>. Accessed: Jun. 10, 2021. doi: 10.1016/j.jprot.2020.103763. 
POSTMA, M. et al. The biosecurity status and its associations with production and management characteristics in farrow-to-finish pig herds. Animal, v.10, n.3, p.478-89, 2016. Available from: $<$ https://bit.ly/3aIFy0o>. Accessed: May, 10, 2020. doi:10.1017/ S1751731115002487.

POTARNICHE, A. et al. The epidemiological background of small ruminant lentivirus infection in goats from Romania. Veterinary World, v.13, n.7, p.1344-1350, 2020. Available from: $<$ https://bit.ly/3iesK6m>. Accessed: Jul. 15, 2020. doi: 10.14202/ vetworld.2020.1344-1350.

RIBEIRO, A. L. C.; GUIMARÃES, S. C. K. Manual de biossegurança. Governo do Estado do Espírito Santo. Secretaria Estadual de Saúde, Laboratório Central de Saúde Pública LACEN, 2017. Available from: <https://bit.ly/31cTEUQ $>$. Accessed: May, 10, 2020.

ROCHA, S. S.; BESSA, T. C. B.; ALMEIDA, A. M. P. Biossegurança, Proteção Ambiental e Saúde: compondo o mosaico. Revista Ciência e Saúde Coletiva, v.17, n.2, p.287-292, 2010. Available from: $<$ https://bit.ly/3aYqYSN $>$. Accessed: May, $10,2020$.

RODRIGUES, A. S. et al. Avaliação de um controle estratégico da artrite encefalite caprina em rebanho caprino leiteiro. Arquivo Brasileiro de Medicina Veterinária e Zooteccnia, v.70, n.1, p.139-146, 2018. Available from: <https://bit.ly/36Azqrf>. Accessed: Sept. 15, 2020. doi: 10.1590/1678-4162-9537.

RON-ROMÁN, J. et al. The unexpected discovery of Brucella abortus Buck 19 vaccine in goats from Ecuador underlines the importance of biosecurity measures. Tropical Animal Health and Production, v.49, p.569-574, 2017. Available from: $<$ https:// bit.ly/31vVTTx > . Accessed: Jun. 22, 2020. doi: 10.1007/s11250017-1229-4

ROSA, F. B. et al. Doenças de caprinos diagnosticadas na região Central no Rio Grande do Sul: 114 casos. Pesquisa Veterinária
Brasileira. v.33, n.2, p.199-204, 2013. Available from: < https://bit. ly/3iXtTOu>. Accessed: May, 10, 2020.

RUI, B. R. et al. Principais métodos de desinfecção e desinfectantes utilizados na avicultura: revisão de literatura. Revista científica eletrônica de medicina veterinária, v.IX, n.16, 2011. Available from: <https://bit.ly/3j9bCOa>. Accessed: Jun. 20, 2020.

SACHET, A. P. et al. Biossegurança em rebanhos leiteiros na agricultura familiar- Sudoeste Paranaense. Archives of Veterinary Science, v.18, n.3, p.28-37, 2013. Available from: <https:// bit.ly/3jcCDA8 $>$. Accessed: May, 15, 2020. doi: 10.5380/avs. v18i3.28839.

SESTI, L. A. C. Biosseguridade em um programa de melhoramento genético de aves. II Simpósio de Sanidade Avícola 14 e 15 de setembro de 2000 - Santa Maria, RS. Available from: $<$ https://bit.ly/3lfnShU>. Accessed: May, 15, 2020.

SILVA, M. G. C. M.; DEL VALLE, T. A. Produção de caprinos Lavras: Ed. UFLA, 2018. 109 p. Accessed: May, 22, 2020.

TEIXEIRA, P.; VALLE, S. Biossegurança: uma abordagem multidisciplinar. 2.ed. Rio de Janeiro, RJ: FIOCRUZ, 2010. 442p. Accessed: May, 22, 2020.

U. S. DEPARTMENT OF AGRICULTURE. Goat Biosecurity. Available from: $<$ http://bit.ly/3c3xQjY>. Accessed: Jan. 18, 2020.

VESCHI, J. L. A. et al. Caracterização de propriedades de criação de caprinos leiteiros localizadas em Petrolina, PE e Santa Maria da Boa Vista, PE. Documentos 273. Embrapa Semiárido Petrolina, PE, 2016. Available from: $<$ https://bit.ly/3noi4ng $>$. Accessed: Sept. 15, 2020.

WILLIS, C. et al. An assessment of the microbiological quality and safety of raw drinking milk on retail sale in England. Journal of Applied Microbiology, v.124, p.535-546, 2017. Available from: <https://bit. ly/3G3zrTY>. Accessed: Oct. 15, 2021. doi: 10.1111/jam.13660. 